\title{
Reconciling Traditional Indigenous Governance with Contemporary Approaches to Decision Making in Ogoni Communities in Rivers State, Nigeria
}

\author{
Nwamaka A. Okeke-Ogbuafor ${ }^{1}$, Tim S. Gray ${ }^{2} \&$ Selina M. Stead ${ }^{1}$ \\ ${ }^{1}$ School of Marine Science and Technology, Newcastle University, United Kingdom \\ ${ }^{2}$ School of Geography, Politics and Sociology, Newcastle University, United Kingdom \\ Correspondence: Nwamaka A. Okeke-Ogbuafor, School of Marine Science and Technology, Newcastle \\ University, United Kingdom. E-mail: n.a.okeke-ogbuafor@newcastle.ac.uk
}

\author{
Received: September 6, 2015 Accepted: November 21, 2015 Online Published: January 26, 2016 \\ doi:10.5539/jsd.v9n1p55 \\ URL: http://dx.doi.org/10.5539/jsd.v9n1p55
}

\begin{abstract}
This paper explores the perceptions of Ogoni people about their system of inherited leadership in Ogoniland, It focuses on whether the Ogoni people believe that their traditional system of inherited leadership has ameliorated or exacerbated the adverse impact of oil capitalism and political interference on their communities. Fieldwork was carried out in eight communities in Ogoniland in early 2014 when 69 key informant interviews were conducted as well as three focus group discussions. The conclusion reached by the paper is that many Ogoni people believe that the system of inherited leadership has let them down in the face of external threats, and that it is time to reform that system by incorporating into it some contemporary western principles of good governance.
\end{abstract}

Keywords: tradition, inheritance, governance, natural and artificial trust

\section{Introduction to Study Area}

Ogoniland is a kingdom located in Rivers state, one of Nigeria's Niger Delta (ND) states. By traditional custom, Ogoni has six subkingdoms of Babbe, Eleme, Gokana, Ken-Khana, Nyo-Khana, and Tai, which are controlled by the area's paramount ruler (UNEP, 2011). But for easy administration by the state, it is divided into four local government areas of Eleme, Gokana, Khana and Tai, and together these areas cover about $1,000 \mathrm{~km}^{2}$, housing a population of about 832,000 people. According to Boele et al. (2001), who cited Kpone-Tonwe, the Ogoni people settled on their lands over 2,000 years ago and have since depended on these lands for survival in providing a source of income, food security and employment. Land here includes rivers, streams, rivulets and forests from where foods like crayfish, periwinkle and fish were sourced.

Under the agrarian era, Ogoni family heads mediated over disputes and community leaders (chiefs, council of elders) were selected based on chronological age (sometimes adjusted for ability), and since this period (pre-colonial) times, chieftaincy stools have remained hereditary. For example, Dumka in 2008 reported that the Gbenemene Nama stool has been hereditary since the sixteenth century, remaining under the royal family in Sii, which is an Ogoni community within Khana local government area [https://lists.mayfirst.org/pipermail/ friends/2008-October/004137.html]. According to many commentators, this pre-colonial era in Ogoniland was one of stability, self-sufficiency and harmony marked by good local traditional governance. Igbara and Keenam (2013) claimed that before western influence, land cultivation was the main mode of production and was available to almost every member of their community with a lineage, and food crises were uncommon, as there was sufficient land for agricultural production.

However, colonialism undermined this system by monetizing land, and it "became a commodity for outright sale. The collective ownership of land was removed from the village and taken over by the government leaving them...with customary right of ownership" (Igbara and Keenam, $(2013$, p. 54). This paved the way for oil production, since the government was now able to sell/rent land to international oil companies for exploration activities. Oil was discovered in Ogoni by Shell in the 1950s, and following expansion in production, Shell extended its facilities across ND communities, so by 1993, Ogoni had 12 oil fields, 116 wells of which 89 were completed, and 5 flow stations (UNEP, 2011). These wells, according to Pyagbara (2007, p. 5), are linked to Bomu, Bodo west, Ebubu, Korokoro and Yorla flow stations by interconnecting pipelines that run through 
settlements, releasing pollutants mainly through oil spills and gas flares which are toxic to humans and their environment: "gas had been flared for 24 hours a day for 40 years in close proximity to human habitation in nineteen oil locations in a 404 square mile area with a population density of 1,250 per square mile".

Shell's oil development dislocated the link this sect of people had established with their natural environment for over 2,000 years, and the degradation of their land affected their local economy. As Pyagbara pointed out, their once viable farming and fishing kingdom gradually lost its fertile lands and clean waters through pollution, exposing Ogonis to severe hardship as a result of unemployment and poverty (Maduagwu, 2012). The Nigerian state, which granted licences to oil companies like Shell, has not adequately compensated these people, but instead has used resources from this area to develop other parts of the country. Boele et al (2001) cited Detheridge who reported that from the start of production to 1993, the year Shell moved out of Ogoni, about 634 million barrels of oil worth US\$5.2 billion were produced from this area, of which $79 \%$ was remitted to the Nigerian government. Ogoni communities became known for their underdevelopment and rural decay: paradoxically "it is an environment of great wealth as well as inhuman poverty" (Inokoba and Imbua (2010, p. 101). Maduagwu (2012) finds a link between the scarcity of fertile lands, poverty, unemployment and the increasing number of violent attacks and conflicts that have occurred in recent times in most Ogoni communities.

In addition to the damage caused by oil capitalism, Ogoni communities have been exploited by politicians who have solicited them with promises of development in return for electoral support. According to Chigudu (2015, p. 121), "political parties realize the ability by political leaders to communicate information and command respect from their communities and have developed an edge to rally these leaders to their cause during electioneering" (see also Nweke, 2012, and Chinsinga, 2006).

The questions that this paper addresses are: do members of oil-rich Ogoni communities perceive that their traditional inherited systems of leadership have resisted oil companies in an attempt to defend communities against environmental pollution? And do members of oil-poor Ogoni communities perceive that their traditional inherited systems of leadership have resisted bribes from politicians to vote for them? Or did the members of both sets of communities perceive that their traditional chiefs conspired with the oil companies and the politicians, respectively, in order to reinforce their own privileged positions of elite rule, thereby intensifying the damage to their communities?

The rest of the paper is divided into four sections: (2) methodology; (3) theory of inherited traditional leadership; (4) fieldwork results and discussion; and (5) conclusion.

\section{Methodology}

The fieldwork for this study took place between February and May, 2014, the aims of which were: to understand Ogoni traditional inherited leadership structures; to determine their roles in communities; and to obtain the perceptions of respondents about their effectiveness in dealing with the external pressures of oil exploration and political interference. To achieve these aims, a total of 8 communities across the four local government areas (LGAs) of Ogoniland were studied. Five of these communities (Communities 1, 2, 3, 4, and 5) were/are oil-rich and they have Shell facilities or spill locations. For example, Community 1 is known for one of the most notorious spills in the 1970s; Community 2 houses oil manifolds which cover an area of about 5,000 square metres; and Community 3 also has numerous oil wells (UNEP, 2011). The other three communities (Communities 6, 7, and 8) were/are oil-poor. While the leaders of oil-rich communities claim that they get only limited support from oil companies, in truth these companies have sent enormous amounts of cash into contaminated communities to leadership figures in these communities, whereas oil-poor communities have not received such cash (Zandvliet and Pedro, 2002), even though they suffer indirectly from the damage caused by oil pollution in neighbouring communities. Oil-poor communities also suffer disproportionately from government interventions by politicians seeking electoral loyalty. The choice of oil-rich and oil-poor communities as case studies was designed to ascertain whether the traditional system of inherited leadership worked well in oil-poor areas, but not in oil-rich areas which were unable to resist the seduction of oil capitalism; or whether it worked badly in oil-poor areas because of their susceptibility to political interference.

This research used a wide range of informants not only as a way of achieving a variety of perceptions from stakeholders with diverse backgrounds but also as a way of triangulating different data sources. Key informants (KIs) in this research came from church leaders, members and leaders of community organizations, local government staff, ward councillors, local chiefs, members of councils of chiefs and elders, members of community based organizations (active and passive), university teachers, Shell social performance officers, and non-indigenes residents in communities. In total, $69 \mathrm{KI}$ interviews were conducted as well as three focus group discussions. 


\section{Theory of Inherited Traditional Leadership}

The traditional school of African thought believes in the value of inherited leadership as a guide to good conduct as well as a defense against the incursion of damaging western liberal values into African communities (Logan, 2008). Proponents of traditional leadership claim that it is not a rigid system of governance but one that over time has shown some level of flexibility and ability to adapt to changes in communities. In particular, proponents assert that traditional inherited leadership recognizes the dynamism of cultural values and so keeps adjusting to meet the increasing demand for wider participation and respect for human rights (Chinsinga, 2006). This is so because chiefs are aware of their duties, since, according to Gyeke (1996), as cited by Kendie and Guri (nd), their powers are derived from the people and for this reason, there is always a close relationship between the chief and his subjects. Indeed, Chinsinga (2006) states that local people have the power to remove chiefs who fall short of their expectations. If it were an oppressive and discriminatory system, traditionalists argue, it would have ceased existing (Chigudu, 2015). Its very resilience during a period of upheaval brought about by colonial and post-colonial oppression, says its defenders, testifies to its enduring value (Chinsinga, 2006).

Moreover, this institution is an African heritage which has considerable indigenous support, according to its defenders. Traditional leaders are and remain custodians of culture as well as controllers of an effective network of communication, following their ranked structure (chief, council of chief and elders) in communities. This advantage makes replacing this structure with a western model very difficult. Lule (1995, p.11) argued that what matters most is how comfortable Africans are with this tradition, rather than whether it meets western criteria of democracy. In striking terms, Lule (1995, p. 13) asserted that:

"it is surprising that there should be people who would wish to abolish an institution which research has confirmed to be the anchor of stability, social cohesion, development, progress and conservation of culture, while actively championing the preservation of institutions which have over the years brought chaos, suffering, national disintegration and loss of millions"

Chinsinga's findings in Malawi suggest that local people preferred their traditional institutions because they considered them as agents of positive change when compared with elected councillors, for four reasons: their local chiefs are the owners of the villages; they live in the villages and thus fully understand their problems; they resolve conflicts, prevent crime, and ensure that morals are maintained in their communities; and they guarantee that community development projects work.

However, a contrary view of traditional inherited leadership has been expressed by adherents of the modernist school, arguing that this system has no democratic base; hinders social mobility by perpetuating a caste system (Chingudu,2015); endorses widespread discrimination against women (Okome, 2002); and impedes the development of self-rule (Logan, 2008). According to Olowu and Erero (1995, p. 14), the culture of inherited leadership has internal weaknesses: "they are restrictive... as political office is often held for life. They are not entirely transparent...they lack effective managerial skills." Chigudu $(2015$, p. 121) states that "traditional leadership has no place in electoral democracy as it contradicts the very basic values of freedom of choice". Moreover, such critics argue that these flaws in traditional inherited leadership have exacerbated the damage caused by external threats such as colonialism, post-colonialism and oil exploration. For example, Luthe (2007) reported Mamdani's assertion that during colonial times, traditional chiefs were tools of the colonial powers, given enhanced power by their political masters. Chigudu (2015, p. 120) explained that "in post-colonial era, there have been reports of electoral manipulation through the institution of traditional leadership". Pyagbara (2007) claimed that in his Ogoni kingdom, as a result of oil capitalism, these traditional institutions have become agents of disintegration (see also Arisukwu and Nnaomah, 2012). Traditional chiefs facilitated access of oil developers to the land in their communities, thereby conspiring in the resultant environmental damage (Agbonifo and Aghedo, 2015).

It is in the light of this controversy that our research investigated perceptions of traditional leadership in five oil-rich and three oil-poor communities, to ascertain to what extent respondents believed that the damage inflicted by oil exploration and political interference respectively was mitigated by public-spirited traditional inherited leadership, or was worsened by traditional chiefs conniving with oil companies and politicians for personal gain at the expense of their communities' well-being.

\section{Fieldwork Results and Discussion}

The study's fieldwork revealed a similar division of opinion to that expressed in the literature on the value of traditional leadership, between those respondents who strongly defended it and those respondents who strongly criticised it. The defenders included most community leaders in Ogoniland, who argued that the culture of inherited leadership was one legacy from their ancestors that they should preserve. For example, respondent 
KI-18 asserted that "we cannot afford to abandon this culture (inherited leadership)". According to respondent KI-23, "when you meet the leadership of these communities, they provide you with necessary information that you need". Respondent KI-6, an octogenarian leader, claimed that since ascending the throne he has followed the good precedents of his predecessor, his late father. Defenders of traditional leadership claimed it had some built-in safeguards. For instance, respondent KI-17 argued that

"here [Ogoniland] it is hereditary, if your old grandfather was a chief, the throne will never leave your family...even when you are from a royal family, the community will still decide whether you are capable or not, they will pick a capable person [from] outside until they get a capable person from the family".

However, the critics of traditional leadership were far more numerous and vociferous. According to most KIs in the five oil-rich communities, the response of traditional leaders to the presence of oil and Shell facilities was damaging to local communities. For example, KI-26, reported that "local chiefs are the people oil companies use to penetrate our community...they are always in favour of oil companies because of what they get from them". Respondent KI-17, a member of the council of chiefs and an elder of an oil-rich community, asserted that traditional leaders respond to oil companies' funds in their areas in either of two ways; by side-lining their council members, or by ensuring that they connive with them to rob their community. In his own community, respondent KI-17 reported that the former alternative was chosen, and the side-lined council members are unhappy with their chief because

"Shell gave us the opportunity to provide 6 people that will join their clean-up team, our paramount ruler sat down himself and picked 6 people, he picked contractors from wherever he liked, without meeting with CDC chairman or council of chiefs, without a common meeting, he submitted the list to Shell without our notice".

Respondent KI-21 also claimed with regard to his oil-poor community that the latter alternative operated: chiefs conniving with their council members to select officials who will be loyal to him, so these officials "don't confront their traditional leaders, because they are the same people that these chiefs use". Both types of abuse of traditional governance strategy, according to Nweke (2012), have caused many violent conflicts within communities. Youths no longer trust the leadership of their communities, especially community chiefs who receive cash on their behalf from oil companies, and they constantly challenge these leaders, demanding their own share of the oil companies' cash. Likewise, Arisuokwu and Nnaomah (2012, p. 139) claim that traditional chieftaincy stools are losing value and respect to the point that most youths in oil-rich communities no longer subject themselves to the leadership of their communities: "they have become more violent in their approach and this has led to more bloodshed and destructions".

The underlying aim of most of these violent conflicts is to obtain access to the oil money and the 'political' money from politicians seeking electoral positions, both of which are given to chieftaincy stools on behalf of their communities (Nweke, 2012; Zandvliet and Pedro, 2002). The competition for these gifts accounts for some of the worst conflicts that have occurred in this area in recent times. For example, Kialee (2011) reported that Zaakpon community suffered a crisis for five years over challenges to its chieftaincy stool, noting that during this period, in 2005, the entire community was deserted, leaving only cult groups. According to him, these cult members are illiterate young people between the ages of 12-25, who are now hired by local chiefs to wage war on their behalf when there are threats to their thrones.

Table1. Timeline of violent attacks and their causes 2003-2007 (Kialee, 2011)

\begin{tabular}{lllc}
\hline Inter/intra community conflicts & Cause of conflict & Date & Duration \\
\hline Kaani 1 versus Kaani2 & Chieftaincy and councillorship seats & $2003-2007$ & 5 years \\
Zaakpon & Claims over chieftaincy stool & $2003-2007$ & 5 years \\
Kapnoo & Clashes between community cult groups & March 2006-Dec-2007 & 21 months \\
Bodo community & Clashes between community cult groups & July 19-30 2006 & 14 days \\
Kpong & Claims over chieftaincy stool & April-Sept 2007 & 6 months \\
Kono Boue versus Uwegwere community & Clash between cult members & May-Aug 2007 & 4 months \\
Kor community & Claims over chieftaincy stool & June-Aug 2007 & 3 months \\
\hline
\end{tabular}

Ikerionwu (2013) stated that circumstances in both oil-rich and oil-poor communities are not improving for 
Ogonis, as unemployment, poverty and community decay are increasing and there is growing psycho-social degradation. Respondent KI-16 attributed these problems to the poor quality of leadership delivered through the culture of inheritance: " $70 \%$ of our problems here are caused by our chiefs...they just got up and ascended their thrones because their fathers were chiefs". Respondent KI-21 emphasized personal motives of self-enrichment as one reason why traditional institutions of community leadership headed by a chief have failed to work in his oil-poor community because through inheritance, people who ascend chieftaincy stools seek money:

"when they ascend the throne, they wait for the first contract that will come into their community, they use that money as a source to set up themselves, that is why people in this community are not benefitting from the government".

In oil-rich communities, any oil funds sent into the community pass through the hands of these chiefs (Zandvliet and Pedro, 2002). Even advocates of inherited leadership like Kendie and Guri (nd-b, p. 345) admitted that the 'asafo', which is a traditional authority in Ghana, "started conniving with the illegal forest operators for their personal benefit". The suspicion arises, therefore, that traditional inherited leadership has inherent flaws in dealing with any form of resources because its lack of transparency and accountability makes it readily susceptible to corruption.

At the root of some of these deficiencies identified by respondents is poor education. Kendie and Guri (nd-a) pointed to the limited educational backgrounds of local leaders as an important issue that affected the quality of local leadership, arguing that while the attainment of education is not a sufficient criterion for good leadership, it may be a necessary one. Respondent K-63 traced the many problems in his oil-rich community to the poor educational status of its local leaders. For instance, he thought its leaders fell prey to Shell because "our chiefs did not go to school, they were traditionalists that whenever anybody spoke English to them, they will consider that person reliable, they don't know that they were being deceived". This to him explains why politicians are able to manipulate chiefs so easily. Respondents KI-16 and KI-65 thought the chiefs in both oil-rich and oil-poor communities are passive and wait for development, because their poor educational attainments make it hard for them to actively attract development. For Chinsinga (2006, p. 1), chiefs who get involved in partisan politics are vulnerable because "their ill material circumstances render them overwhelmingly easy targets for politicians bent on satisfying their own strategic political considerations". KI-28 questioned how these communities will develop when their community leaders "do not bother to attract development...companies here are looking for indigenes to employ but their community leaders go there take the spaces, sign and sell them out to non-indigenes, how do you expect this place to grow?"

For another reason, respondent KI-21 held that the poor educational status of chiefs could destabilize communities: educated members of his oil-poor community find it extremely difficult to subject themselves to the leadership of a non-educated chief and claimed that this was the major cause of the seven years' crisis that befell his community:

"our lower chief use to say that the higher chief is not presentable because of his level of education... they don't always agree to whatever our highness says...they see their senior as inferior and not intelligent and because of this on several occasions the high chief has danced to their tune but the councillorship elections led to their major disagreement and this caused us over seven years of instability".

Respondent KI-2, a chief of an oil-poor community, explained that community chiefs get involved in politics out of external pressure to deliver their communities electorally to politicians. Respondent KI-12, leader of community women, openly admitted that the linkage between her leadership in her community and the ruling party in her state is purely for personal gains:

"am now the new women leader of All Progressive Congress (APC) party in my community, I decamped from Peoples Democratic Party (PDP), am a politician ...they have asked me to ensure that all...women vote for APC at all levels. When I was in PDP I gave each of them (women) wrappers and cash. We (community leadership), will work together to deliver to APC, our gain will be 50-50 (equally)".

KI-28 reported that community chiefs and council members take advantage of their poor subjects: "one politician can buy off the whole community through their leaders". This, according to KI-19, explains why "Ogoni has been vulnerable to violence...they got themselves divided along different political lines". KI-67 stated that leadership of communities (oil-rich and oil poor) headed by chiefs utilize "any slightest opportunity that they have to take money" from politicians, ignoring the destructive consequences of party politics on their communities. Agbonifo and Aghedo (2015, p. 154) claim that Ogonis in both oil-rich and oil-poor communities feel "betrayed and disinherited by their supposed leaders", and noted that it is for this reason that youths named 
their chiefs 'vultures'. KI-29 argued that as a result, "Ogoni is lawless, nobody respects anybody, any young boy can do whatever he likes because no authority can call him to order, ordinarily they are supposed to report him to the leadership of the community, but is not possible they are themselves, lawless".

These forms of corruption have exacerbated the threats to both oil-rich and oil-poor communities' development in Ogoniland for 20 years (Kialee, 2011). Yet, according to respondent KI-64, Ogoni culture permits chiefs to remain on their thrones and "not much can be done to them because of the fear that if he is changed something bad will happen in the community, fear will not even allow people to question them". KI-16 narrated his experience with the Nigerian police over a case of corruption against his community chief:

"I wrote a petition against our chief, the commissioner of police invited him and after interrogation, the police asked us to settle it because of tradition. In our kind of society if anybody hears that I arrested the chief, they will blame me not minding our chief's offence, I will be seen as the greatest offender. After considering all these I thought it was wiser not to pursue the case any further".

It is also because of this tradition that ailing chiefs are not readily replaced. Respondent KI-68 reported that his oil-rich community remained dormant for about five years because their chief suffered from a stroke. Indeed, there is no form of accountability or avenue for recourse against misuse of or incapacity for power (Chigudu, 2015). Respondent KI-65 from an oil-poor community reported that his community chiefs "just give out titles and the title holders don't research deeply to know what they are supposed to be doing and what they are not supposed to do".

These criticisms of traditional leadership may be summed up by the statement from KI-67 that "style of leadership and administration matters so much. If a chief cannot organize his people, if he lives a life that is questionable or suspicious there must always be problems in his community" (KI-67).

Several respondents argued for reforms. For example, respondent K-53 from an oil-rich community thought his community can only achieve peace and development when they "remove all our leaders because they are not helping us, there are good people that can represent us very well'. Respondents, KI-54, 50 and 57 argued for the state and other external interventionists to bypass their local chiefs and deal directly with individuals in the community. For example, respondent KI-54 claimed that "if government can help us directly without going through our leaders, our lives will change". Some communities (both oil-rich and oil-poor) have made significant efforts to reform their systems of traditional inherited leadership to guard against corruption. For example, Ogoni communities have introduced three innovations in governance: (1) rotating; (2) parallel; and (3) complementary.

The 'rotating' system is the first attempt made in some oil-rich communities to replace incumbent chiefs. It involves elections conducted usually by the council of elders, who with external support depose incumbent chiefs. Elections here are not open to the public - only selected community members may participate. According to KI-68, who is both a member of the council of chiefs and an elder in his community, the aim of this innovation is to ensure that more capable hands ascend their throne and also that community wealth does not end up in the bank accounts of the royal family, but is equally enjoyed by other council members. Wealth here includes royalties paid by companies, job allocations, and community scholarships. However, KI-14, a former community chief and victim deposed through this system, criticized it, claiming that "Shell colluded with some of our people, on their own they elected in another chief. My people ganged up with Shell against me, before I knew what was happening there was an order on my throne".

The 'parallel' system entails the existence of a permanent opposition to the incumbent local chief. This opposition usually comes from more educated members of the community. KI-63 thought it was time more learned people took over the leadership of his oil-rich community: "we ( [learned members of our community] are ashamed of ourselves because of the events that happened in our community...some time ago, buildings were razed, even just within four months, we had four paramount rulers, our people fought against each other, we passed through hell". He said that it was for these reasons that educated members of his community formed an 'elites club' which conducted elections for chieftaincy stools in his community, though after the stool was occupied by an educated person, their dethroned chief fought back. While this 'radical' form of opposition was observed mainly in oil-rich communities, the most common form of parallel structure is the 'moderate' or pluralist form, wherein council members (youth, women, chairmen of the council of chiefs and elders as well as chairmen of community development committees), oppose each other. This moderate form is common in all eight communities studied.

The 'complementary' system is a more consensual and harmonious relationship between formal and informal governing bodies. For instance, it occurs where community elites (learned) people work together with their local 
chiefs. This innovation was observed in Community 4, where members of the community social club work closely with their local chief. According to KI-2, KI-8, KI-25 and KI-64, members of this club recognized the shortcomings of their local chiefs and institutions and so got involved to remedy them in a cooperative way.

Critics may argue that these three innovations are only modest improvements on the traditional inherited system of leadership, since none of them is democratic. The rotating system is usually built from the relics of the former incumbent structure and so the only difference may be the change in the lineage of the elite; both the radical and moderate forms of the parallel structure restricted the franchise to the elite; and the complementary system is consensualism between elites.

\section{Conclusion}

From our research, it is clear that while Ogoni respondents hold that oil capitalism and political bribery have been largely responsible for a sharp deterioration in their community well-being, they see shortcomings of the traditional inherited leadership system in Ogoniland as a major contributory cause. These shortcomings include criticisms of traditional leaders for failure to embrace an accountable leadership style; to provide a peaceful environment for their subjects; and to seek development rather than wait for it. Moreover, respondents regret that the traditional structure has not provided any opportunity for the led to choose their leaders or express their concerns; hence the upsurge in conflicts over contested structures of governance in many communities. According to respondents, maintaining this traditional form of inherited leadership is akin to maintaining a caste system, which instead of promoting communality, diminishes it.

Our conclusion, therefore, is that Ogonis believe there are inherent flaws in the traditional inherited leadership system in Ogoniland that has made it easily susceptible to seduction by oil capitalism and political interference, thereby exacerbating rather than ameliorating the environmental damage done to their communities by oil production. Efforts have been made to reform the traditional system to make it more resistant to corruption, but these efforts have so far been timid. In our view, what is needed is more vigorous reform to make traditional leaders more responsible to their people. Because the reliance on 'natural trust' in traditional leaders has failed to provide good governance, we should try 'artificial trust' by applying contemporary western principles of good governance such as accountability, transparency, and fairness. One way to implement these principles is by giving community members the opportunity to elect people who can work with local chiefs, thereby integrating traditional and modernist systems of governance. While critics of electoral processes may argue that elections are far from perfect, this paper sees more serious problems in retaining a virtual caste system where citizens are treated as objects rather than as subjects.

\section{References}

Agbonifo, J., \& Aghedo, I. (2015). Leadership Assassination and Movement Survival: the Ogoni and Islamic Movements in Nigeria. Sokoto Journal of the Social Sciences, 2(1), 148-169.

Arisuokwu, O., \& Nnaomah, K. (2012). Shell Petroleum Development Corporation Oil Exploration and Socio-economic Life in Ogoni, Nigeria. Journal of Sustainable Development in Africa, 14(8), 132-138.

Boele, R., Fabig, H., \& Wheelers, D. (2001). Shell, Nigeria and the Ogoni. A Study in Unsustainable Development: the story of Shell, Nigeria and the Ogoni people-Environment, Economy, Relationship: Conflict and Prospects for Resolution. Sustainable Development, 9(2), 74-86. http://dx.doi.org/10.1002/sd.161

Chigudu, D. (2015). Assessing Policy Initiatives on Traditional Leadership to Promote Electoral Democracy in Southern Africa. Mediterranean Journal of Social Science, 6(1), 121-124.

Chinsinga, B. (2006). The Interface between Tradition and Modernity: The Struggle for Political Space at the Local Level in Malawi, pp. 255-274. Retrieved from http://civilisations.rewes.org

Igbara, P., \& Keenam, B. (2013). Ogoni in Perspective: An Aspect of Niger Delta History. Port Harcourt, Nigeria: Onyoma.

Ikerionwu, I. (2013). Movement for the Survival of the Ogoni People: A Case of Non-violent Campaign against Environmental Degradation. Retrieved from http://www.academia.edu/34972

Inokoba, P., \& Imbua, D. (2010). Vexation and Militancy in the Niger Delta: The Way Forward. Journal of Human Ecology, 29(2), 101-120.

Kendie, S., \& Guri, B. (n.d.a). Indigenous Institutions and Contemporary Development in Ghana: Potentials and Challenges. Retrieved from http://www.cikod.org.../indigenous\%20institutions\%20and\%20co 
Kendie, S., \& Guri, B. (n.d.b). Indigenous Institutions, Governance and Development: Community Mobilization and Natural Resources Management in Ghana. pp. 332-348. Retrieved from $\mathrm{http}: / / \mathrm{www}$. researchgate.net/.../23780383_indigenous-institutions-governance

Kialee, N. (2011). From University Campuses to Villages: A study of Grassroots Based Cult Violence in Ogoniland, Eras 12(2), 1-35.

Logan, C. (2008) Traditional Leaders in Modern Africa: Can Democracy and the Chief Co-exist?. Afrobarometer working paper No 93, pp. 1-23. Retrieved from http://www.afrobarometer.org/fi

Lule, G. (1995). The Role of Traditional Leaders in the 21st Century, pp. 1-15. Retrieved from http://www.federo.org/index.php?id=188

Luthe, D. (2007). Rural Local Governance in Post-Colonial Zimbabwe: A case Study of Zimnyama Ward in Bulilimamangwe District (Published master's thesis). University of Cape Town.

Maduagwu, C. (2012). Effect of Oil Pollution on the Socio-Economic Life of Ogoniland, Rivers state (Unpublished master's thesis). National Open University of Nigeria.

Nweke, K. (2012). The Role of Traditional Institutions of Governance in Managing Social Conflicts in Nigeria's Oil-Rich Niger Delta Communities: Imperatives of Peace-Building Process in the Post-Amnesty Era. British Journal of Arts and Social Sciences, 5(2), 202-216.

Okome, M. (2002) Domestic, Regional, and International Protection of Nigerian Women Against Discrimination: Constraints and Possibilities. African Studies Quarterly, 6(3), 35-54

Olowu, D., \& Erero, J. (1995). Governance of Nigeria's Villages and Cities through Indigenous Institutions, p. 14.

Pyagbara, L. S. (2007). The Adverse Impacts of Oil Pollution on the Environment and Wellbeing of a Local Indigenous Community: The Experience of the Ogoni people of Nigeria', International Expert Group Meeting on the Indigenous People and Protection of the Environmen. Retrieved from http://www.un.org/esa/socdev/unpfii/.../workshop_IPPE_pyagbara.doc

UNEP. (2011). Environmental Assessment of Ogoniland, pp. 1-32. Retrieved from http://postconflict.unep.ch/publications/OEA/UNEP_OEA.pdf

Zandvliet, L., \& Pedro, I. (2002). Oil Company Policies in the Niger Delta, pp. 2-26. Retrieved from http://www.cdacollaborative.org/media/60997/Oil-company-policies-in-the-Niger-Delta.pdf

\section{Copyrights}

Copyright for this article is retained by the author(s), with first publication rights granted to the journal.

This is an open-access article distributed under the terms and conditions of the Creative Commons Attribution license (http://creativecommons.org/licenses/by/3.0/). 